International Journal of English Literature and Social Sciences
Vol-6, Issue-1; Jan-Feb, 2021

\title{
Spirituality in Human Being and Nature: Ecocriticism Has Yet to Comply
}

\section{Dr. Raju Chitrakar}

HOD/Coordinator, Department of English, Tribhuvan University, Padmakanha Multiple Campus, Bagbazar, Kathmandu, Nepal

Received: 05 Dec 2020; Received in revised form: 21 Jan 2021; Accepted: 08 Feb 2021; Available online: 18 Feb 2021 (C)2021 The Author(s). Published by Infogain Publication. This is an open access article under the CC BY license (https://creativecommons.org/licenses/by/4.0/).

\begin{abstract}
Anthropocentrism has still been the dominant approach of human and nature relationship. It takes human being as the master and nature as created to fulfill their needs. Spirituality in human being and nature is beyond its speculation. However, there has emerged non-anthropocentrism known as ecocriticism, which views human being as a part of nature, not its master. It is similar to spiritualist claim of human and nature affinity, but it also does not admit any form of spirituality in human being and nature. The argument of this paper is to postulate the fact that spirituality is one of the fundamental elements of both human being and nature. If ecocriticism would adopt this, it would emerge as a complete alternative of anthropocentrism, whereby most problems of the world could be solved.
\end{abstract}

Keywords-Adhyatma, anthropocentrism, ecocriticism, soul, spirituality.

\section{INTRODUCTION}

Ecocriticism is the latest approach of studying human and nature relationship. It is an earth centered approach. It studies human and nature relationship on the physical ground. However, the objective of this paper is to show spirituality in human being and nature. It claims that spiritual elements are embedded within human being nature. Without realizing this substantial reality, true relationship between human being and nature cannot be discerned and applied. When it is established, prevailed colliding relationship between them could be resolved. It thereby could help maintain peace, stability and development in the world in the true worth.

In this paper, I first present anthropocentrism and ecocriticism as the paradigms of making human and nature relationship. While doing this, I focus on their missing of giving spiritual attribution to human being and nature. Then I define in brief what spiritualism is. After that, I present how human being and nature are spiritual. And then I show the need for ecocriticism to comply with spirituality. I supply conclusion from these.

\section{ANTHROPOCENTRIC RELATIONSHIP WITH NATURE}

Anthropocentrism is the west generated still dominant paradigm of making human relationship with nature. It keeps human beings at the center and nature in the margin. It takes nature as made for human being to use. It brings Greeko Roman traditions and Judeo-Christian notions for its support. In the Bible it is has been written that God produced all other things and finally produced human being: "God said, let us make man in our image, after our likeness: and let them have dominion over the fish of the sea, and over the fowl of the air, and over the cattle, and over all the earth" (Holy Bible 1-2). This gave human being scriptural license to exploit nature. Lynn White Jr. writes, "Christianity is the most anthropocentric religion the world has seen" (43).

Anthropocentrism works mainly with two assumptions. The first is an assumption that human being is the master of nature as licensed by Genesis, stated above, and hence he is free to use the assumed to be finite or cornucopian nature however he fancies. The second is the assumption that human capabilities can overcome environmental challenges. Hence the stronganthropocentric conviction is that the more humans use nature the more they develop. With this conviction, 
discourses of strong-anthropocentrism present positive human outcomes from the unrestrained use of nature. So humans make unrestrained exploitation of nature.

Such a differential practice generated western dualistic or hierarchical philosophy. Concept of differences between the people of one place and another, one ideology and another, one religion and another, one ethnicity and another, one gender and another, and so forth are the results of this dualistic philosophy. As a result, this has been one of the main causes of the conflicts among the people of such groups. Spirituality in human being and nature is beyond even the imagination of this anthropocentric concept of human and nature relationship. Such a logocentric or hierarchical philosophy has made human being shallow, making it to strive just for passion or possession. Like the statement of White stated quoted above, ecocritics take anthropocentrism as a problematic.

\section{NON-ANTHROPOCENTRIC/ECOCENTRIC RELATIONSHIP WITH NATURE}

Ecocriticism is one of the recently emerged paradigm of literary criticism which also studies human and nature relationship. Its concept arose in 1070s, was developed in the organized manner in 1080s, and its theoretical cannons were devised in 1990s. It adopts biocentric approach of human and nature relationship. Finding human being strongly connected to nature, it takes human being as a part of nature, not its master, and hence claims that human being has no right to exploit nature. It values intrinsic worth of the whole objects of nature. So it aims to replace anthropocentrism with nonanthropocentrism. This aim of ecocriticism is acceptable.

However, ecocriticism has also a problem. Realization of the ecocritical position and aim are not easily possible in the people motivated by the impulse of possession. Furthermore, its proponents claim ecocriticism to be a purely an earth centered approach of human and nature relationship. But the problem is that like anthropocentrism, ecocriticism also does not give any room for spirituality. Charily Glotfelty says that "human culture is connected to the physical world, affecting it and affected by it" (xix). To understand ecocritical position and apply it into practice in the true sense, one has to apply spiritual awareness.

What the practitioners of ecocriticism need is the click of what the Vaidic Rhisis called as Brahma Sutra, knowledge of the infinite termed as the 'soul,' the origin of existential reality. To have the knowledge of this fundamental but unperceivable reality is all a spiritual matter. However, it does not mean that one who has the knowledge of this fundamentally spiritual reality is not physically realistic. Filled with spiritual knowledge, people of Vaidic or Satya Yuga, the age of truth, were worldly, cooperative, unproblematic, solaced and hence happy. However, it does not mean that they did not collect material. Only that they kept it in balance as per the need. So only from spiritual knowledge, the aim of ecocentrism can be fulfilled, not from dualism. Ernest Thompson opines, "The great need of our time is a philosophy, which can harmonize the facts of both the spiritual and material aspects of existence in one general synthesis of all knowledge" (2). What he has indicated is the need of a philosophy which synthesizes both physical and spiritual. The fact is that within physicality spirituality is imbedded as it is the optimum level of physicality.

\section{SPIRITUALITY AS THE SUPREME SCIENCE OF EXISTENCE}

Spirituality is the quest of meaning, purpose and direction of human life. Whole Sanatan known as Hindu philosophy strove for it. It took spirituality as Paravidya, supreme science about what is beyond physical reality. In Sanskrit, spirituality means Adhyatma, a coinage of two words, Adhi -the beginning, and Atman -the soul, denoting the meaning that it is a study of the beginning which starts from the soul. Adhyatma takes that what is outside in the universe is inside your body also. So it observes inside and verifies the synthesis devised from it outside. It finds soul as the core of life, the main component of the subtle body of all living beings. When physical body becomes too weak to hold, the soul leaves it. All elements of body then mingle with their respective earthly elements. In the spiritual science, it is not death but transformation into another form. And hence Aghyatma takes soul immortal.

Thus Adhyatma takes true state of human being immortal as it is a part of the soul, which is unaffected by earthly phenomenon. When one understands this and mingles oneself with the soul, one is liberated. But if one is attached to the body, one does not know about the soul as the God seated in him or her and hence falls in troubles and miseries. Agreeing all these, Thompson concludes, "Spiritualism ... provides effective and appropriate spiritual guidance to the solution of man's present world problems" (64). Spirituality is not only the science of solving "present world problems" but also of giving one liberation in which permanent happiness is imbedded.

\section{SPIRITUALITY IN HUMAN BEING}

As spirituality is transcendental, one may argue that human being is empirical by nature. Unlike this I believe that human being is spiritual by nature. I agree with our Rhisimunies' concept of the soul, the ethereal or undetectable component of five earthly matters: earth, water, fire, wind, and sky. The soul lives in all forms of life, 
no matter plant, or animal including human being, until it has the energy -the accumulated power of the earthly elements - to hold it. As I have already talked about it above, let me supply other evidences of humans being spiritual.

Creative human mind itself is fundamentally spiritual in nature. It is the part of body, but it cannot be controlled by body. Instead, body is controlled by mind. So in "The Mind as Distinct from the Body" C. E. M. Joad concludes, "In conclusion ... mind ... is .... independent of the brain, and in virtue of its independence is able to direct and control the material constitutions of the body" (386). He is indicating towards spiritual feature and ability of mind.

Human language is the product of mind. As language is arbitrary and suggestive in nature, it is spiritual by nature. We take it objective only because we know its signification or reference due to over use. Sanskrit is the first written script of the world. And it is our Rhisimunies who first coined written language letter by letter and gave every letter some God's attribution. For instance, aum is the mixture of three sounds a $\mathrm{u} \mathrm{m}$. It is taken as the representative of the soul, the origin of the earth, and hence is given the name as God, the creator, for convenience. From the repeated utterance of this letter, one is likely to attain the soul or God if one becomes able to assimilate oneself with the existence by means of realization and practice of the soul. As to aum, other Godly attributions are given to other letters (108 Upnisad 10). By this what our sages mean is that language is the means of attaining the soul. As soul is all a spiritual matter, general people naturally feel difficult to understand it in the form of a concept. So the Vaidic Rhishimunies named the omnipotent soul as God. And so, all Gods are manifestations of the soul in one or another way. When men assimilate themselves to the order of nature or the universe by making their conducts as per the order of nature or the universe, they attain soul as it is in everything. This is the reason of Lord Krishna's telling to Arjuna that he is the mountain, the elephant, and all other objects of the earth. When one attains this omnipotent soul, one is liberated, which is the optimum aim of all Vaidic spiritual literature.

No matter in different way, Siddarth Gautam became Gautam Buddha through his spiritual journey to the self. He declined the concept or existence of soul. For him, what is real is the nirvana, the state of supreme realization, the state of assimilating oneself with the earth. This is not fundamentally different from the concept of soul; it is different only in name. So did Chinese Taoism and Confucian one way or other. Japan's Shinto is also a nature worshiping religion that believes God in animals, trees, rice fields, and human beings. Linking them with other traditions, T. Yamauchi writes, "Buddhism, Taoism, and Confucianism found their way into this religious context" and hence "melded into naive Japanese traditions" (6). They all connected themselves with nature or cosmos by means of spirituality and guided people for the same. As their preaching, signification of literary or any form of art produced by mind is naturally spiritual as in both -art and spirituality -reasoning is needed. From all these it can be said that spirituality is human element.

\section{SPIRITUALITY IN NATURE}

Question arises, if human being is spiritual, what is nature? Ecocriticism as a philosophical institution of studying human and nature relationship studies nature in the physical ground, which I have presented above. Glotfelty writes, "Simply put, ecocriticism is the study of the relationship between literature and the physical environment.... It takes an earth-centered approach to literary study" (xvii). However, I don't accept this claim in the absolute sense. It can be assumed that if human being as a part of nature is spiritual, as shown above, nature must also be so. I have indicated earlier that effort of spiritualism is to make one assimilate with the order of nature.

American transcendentalism is another nature oriented movement beside ecocriticism. Unlike ecocriticism, it is a spiritual movement in a great sense, and hence the name 'transcendentalism'. According to Ralf Waldo Emerson, "the act of seeing and the thing seen, the seer and the spectacle, the subject and object, are one" ("Over-Soul 131). Human being as one of the species of nature can attain this state of oneness with nature or the universe by means of spirituality. Animals and other species already have this quality because they are in the order of nature. They follow the spiritual order of nature by being physical.

Let me bring an example. Animal Planet and National Geography are some of my favorite channels. I often remember one of their episodes: A family of dogs go hunting very far. One of the dogs rests in the meditative posture in a semi-cave of a hillock on their way. His other members return and sit around him. After a while, he starts howling at them indicating that if they do not go, they will die of hunger as he is going to leave this physical life. Others must have realized it: they leave him alone after a while. The dog's realization is all spiritual like that of the enlightened Hindu or Buddhist sages as they embed themselves with nature and drop their physical body this way, which is called Samadhi.

Here is one more episode. On the second of March 2019, Dr. Anand Sharma presented a paper in the Annual Conference of Literary Association of Nepal. In his paper, he inserted a real episode of one of the families of African elephants: One man used to feed the family of the wild animal time and again. He could not meet and feed the 
family for a long time. After a while he died. After some time of his death, there came the whole family of the elephant to his home of their unknown vicinity by walking around ten kilo miters. They were totally silent and did not search to their loving human friend. They sat there in their mourning mood and posture for around one and half hour and then left. A curiosity arises, how they may have known about their loving human friend's death! It can be reasoned that they knew about his death from their spiritual contact.

A peacock of a million years ago must have danced as beautifully as the present one. Isn't it an instance of immortality, the domain of spirituality? What made it possible but the transfer of soul from one generation to another. These prove that like humans, nature is also spiritual. Thomas Moore writes, "Nature not only reveals that God is present in the world in which we live, but it also teaches us different kinds of spirituality that make up a devout life. Nature then is not a commodity but a source of self-reflection and contemplation" (184). This is his apt explanation of spirituality embedded in nature. Like Emerson, he takes spirituality lurked behind nature as God.

\section{NEED FOR ECOCRITICISM TO COMPLY WITH SPIRITUALITY}

Without being spiritual human beings cannot realize that they are the part of nature. Without it even a highly gifted scientist cannot reach the ultimate reality. Albert Anstine, the authority of the modern physics, emptied everything from his vacuum chamber. Even then he found some sound there. He could not know how this sound was produced. He went to a sage of Burma. The sage told him that he came too late, as he was not energetic enough to bear the endurance in his journey of spirituality. In his death bed Einstein said that he was dying ignorant. What he did not know is that beyond physical science also there is one higher science to which Hindu sages termed as the Paravidya, the science of soul, Brahma, aum, or nirvana, or so which originates or represents all the objects and elements of the universe.

It becomes evident that men will remain ignorant and continue creating problems in the world until they follow the peaceful order of nature by means of higher science of spirituality. We get spiritual significance in all the objects of nature: "All things are moral; and in their boundless changes have an unceasing reference to spiritual, "writes Emerson in Nature (510). Like him, Scott Slovic feels necessity of studying nature: "In today's society one of the most basic roles of environmental writers and their scholarly commentators is simply to redirect our attention to the world beyond human construction -to make us pay more attention to ourselves and to nature" (226). His world of "human construction" is the world of physical science.
What he is indicating is the need of higher science that can study the matrix that is beyond physics or natural science. But what he does not know is that spirituality is the kind of his envisioned science that had been well explained by the Vaidic Rhisimunies. The western world does not have necessary knowledge about their spiritual science. Being one step nearer to nature than others, the practitioners of ecocriticism are the immediate ones who can learn from the east, especially from the Vaidic Rhishis who discovered and well presented the science of spirituality, whose optimum aim is to show oneness of all objects of the world, thousands of years ahead even of the speculation of the modern thinkers about human and nature affinity. Thus ecocriticism has still to learn a lot from the spirituality of human being and nature, which was the great source of the wisdom to the Vaidic Rhishis.

\section{CONCLUSION}

In conclusion, when you are spiritual or Adhyatmic, you are insider. You find everything of the outside within and whereby you become worldly. Then physically you are as you were before, but spiritually you are one with the universe. In the past, your world was narrow, possessive and hence problematic. But now it is wide, cooperative, unproblematic and immortal as you are united with the universe which is immortal. However, anthropocentrism is still the dominant world view. As it gives human being the central focus, other objects of nature are exploited. Ecocriticism is one step ahead of it as it takes holistic approach to human and nature relationship. It gives intrinsic worth to nature. However, only from this, human and worldly problems cannot be solved. Without spiritual journey, humans cannot get the cognition that they are like nature and hence formulate their conducts accordingly. All the worldly problems remain stuck there. Thus, as a hopeful existed philosophy of connecting human beings with nature, ecocriticism has yet to comply with spirituality of human being and of nature and mold human conducts as per the order of nature. From it, humans would know and feel their connectivity with nature or the universe a bit earlier, whereby problems of the world could be solved a bit earlier too.

M. Vannucci writes, "... 'great happiness' means 'perfect knowledge' or the transcendental of Brahman; we could perhaps add: also means factual knowledge" (9).

\section{REFERENCES}

[1] Emerson, Ralf Waldo. "Nature." The Norton Anthology of American Literature. Gen. ed. Nina Baym. $5^{\text {th }}$ ed. Norton \& Company Inc., 1999 pp. 496-525.

[2] ... "Spiritual Laws." Ralf Waldo Emerson: Essays and Poems. Ed. Tony Tanner. Everyman, 2009, pp. 65-82. 
[3] Glotfelty, Charily and H. Fromm, eds, The Ecocriticism Reader: Landmarks in Literary Ecology. Georgia UP, 1996.

[4] Holy Bible. The Gideons, nd. Joad, C. E. M. "The Mind as Distinct from the Body." Philosophy and Contemporary Issues. $9^{\text {th }}$ ed. Eds. John R. Burr, Milton Goldinger. Prentice Hall of India, Pvt. Ltd., 2008, pp. 382-387.

[5] Moore, Thomas. The Soul's Religion: Cultivating a Profoundly Spiritual Way of Life. Harper Collins Publishers Inc., 2002.

[6] 108 Upanisad. Ed. Shreeram Acharya. Brahmabarsh, Haridwar, 2002.

[7] Slovic, Scott. "Ecocriticism: Containing Multitudes, Practicing Doctrine." The Green Studies Reader: From Romanticism to Ecocriticism. Ed. Laurence Coupe. Routledg, 2000, pp. 160- 162.

[8] Thompson, Ernest. Spiritualism in the Evolution of Philosophy. Psychic Book Club, 1953.

[9] Vannucci, Marta. Human Ecology in the Vedas. D. K. Printworld P. Ltd. 1999.

[10] White, Lynn, Jr. "The Historical Roots of our Ecological Crisis." Ecocriticism: The Essential Reader. Ed. Ken Hiltner. Routledge, 2015, pp. 39-46.

[11] Yamauchi, T. "Japanese Religion and Nature." Encyclopedia of Environmental Ethics and Philosophy. Vol. II. Editors in Chief. J. Baird Callicott and Robert Frodeman. Gale Cengage Learning, 2009. 